\title{
Rapid and simultaneous detection of 6 types of human herpes virus (herpes simplex virus, varicella-zoster virus, Epstein-Barr virus, cytomegalovirus, human herpes virus 6A/B, and human herpes virus 7) by multiplex PCR assay
}

\author{
Toshio Tanaka ${ }^{1}$, Kazuhiro Kogawa ${ }^{2}$, Hidenori $\mathrm{Sasa}^{3}$, Shigeaki Nonoyama ${ }^{2}$, Kenichi Furuya ${ }^{3}$ and Kenji $\mathrm{Sato}^{1}$ \\ ${ }^{1}$ Biomedical Laboratory Sciences, Graduate School of Health Care Sciences, Tokyo Medical and Dental University, 1-5-45, Yushima, \\ Bunkyo-ku, Tokyo 113-8519, Japan; and ${ }^{2}$ Department of Pediatrics and ${ }^{3}$ Department of Obstetrics and Gynecology, National Defense \\ Medical College, 3-2, Namiki, Tokorozawa, Saitama 359-8513, Japan
}

(Received 23 June 2009; and accepted 31 July 2009)

\begin{abstract}
A multiplex PCR assay was developed that enabled the simultaneous detection of DNA from 6 types of human herpes virus, HSV-1/2, VZV, EBV, CMV, HHV-6A/B, and HHV-7, using appropriate primer sets and conventional PCR techniques and instruments, with PCR products for each type of virus designed to be easily distinguishable by size. Electropherograms obtained from conventional agarose gels showed that, for each type, the observed number of base pairs corresponded to the intended product and that bands were easily distinguishable from each other. A minimum of 20 copies of viral DNA in a reaction was sufficient to confirm the existence of each of the 6 types of human herpes virus. Comparison of the data obtained from this method and the data obtained from conventional TaqMan PCR using clinical specimens from various sources showed consistent results. The multiplex PCR method reported here for the detection and differentiation of human herpes viruses did not require special equipment or techniques such as hybridization analysis and sequencing analysis and, therefore, enabled us to easily and rapidly detect and identify the 6 types of human herpes virus using conventional methods.
\end{abstract}

Eight types of human herpes virus have been identified: herpes simplex virus 1 (HSV-1), herpes simplex virus 2 (HSV-2), varicella-zoster virus (VZV), Epstein-Barr virus (EBV), cytomegalovirus (CMV), human herpes virus 6 (HHV-6), human herpes virus 7 (HHV-7), and human herpes virus 8 (HHV-8) (20). Infection with a herpes virus can remain latent for decades and eventually cause various clinical symptoms; in many cases, the infection manifests itself as an opportunistic disease $(4,8,10,14,17,26,27)$. Several anti-viral drugs that are effective for treating herpes virus infections have been developed and are now routinely used in treatment $(1,2,18,19,21)$. However, because different human herpes viruses

Address correspondence to: Dr. Toshio Tanaka 2-10-18-202, Owada, Hachioji, Tokyo 192-0045, Japan Tel: +81-42-642-7867, Fax: +81-42-642-7867

E-mail: toshiot@k4.dion.ne.jp often elicit similar clinical symptoms, there is an increasing need for the accurate and timely diagnosis of herpes infections in order for these powerful antiviral drugs to be used effectively $(5,7,14,15,22$, 26).

Recently, a polymerase chain reaction (PCR) method has been developed that is specific for each virus and serves as a rapid diagnostic method. Realtime PCR is also now available for quantitative genome-specific analysis of viral infections $(9,11-$ 13, 23, 24). The conventional PCR method requires the individual examination of each virus, which leads to problems with respect to time and cost. Although PCR techniques that can simultaneously detect human herpes viruses have been reported, amplification product analysis requires complicated methods such as southern blot hybridization (28) and microarray technology (29) to detect many viruses. Furthermore, there are few reports of the 6 
most commonly detected types of human herpes virus (HSV-1/2, VZV, EBV, CMV, HHV-6A/B, and HHV-7) being detected in combination simultaneously. The only other detection method that has been reported is a multiplex PCR technique that involves multiple tubes and requires expensive apparatus (22). All of these methods have problematic requirements regarding facilities or techniques that must be overcome before these methods can be introduced into routine clinical practice in general laboratories such as those found in urban hospitals.

We developed a multiplex PCR technique that can simultaneously detect the 6 most common types of human herpes virus with a PCR reaction in a single tube. Our aim was to develop a standard screening procedure that can be widely used by combining a common PCR method with agarose gel electrophoresis, without having to utilize special methods or expensive apparatus.

\section{MATERIALS AND METHODS}

Source of DNA. DNA was extracted from the following sources: 1) tissue culture-grown viruses, namely, HSV-1 (VR-3 strain), HSV-2 (UW-268 strain), VZV (Batson strain), CMV (AD169 strain), HHV-6A (clinical isolate), HHV-6B (HST strain), HHV-7 (KHR strain), adenovirus type 2 (AdV-2), and simian virus 40 (SV40); 2) virus-carrying cell lines, namely, Raji cell line for EBV, BCP-1 cell line for HHV-8, TL-Om1 cell line for human T cell lymphotropic virus type I (HTLV-I), and CasKi cell line for human papillomavirus type 16 (HPV-16); 3) World Health Organization (WHO) international standard plasma for hepatitis B virus (HBV; National Institute for Biological Standards and Controls [NIBSC] cord 97/746) and parvovirus B19 (NIBSC cord 99/800); 4) Ramos cell line for human genomic DNA; and 5) clinical specimens (obtained from the Department of Pediatrics, National Defense Medical College, Tokorozawa, Japan, after obtaining approval from the institutional review board).

For evaluating the detection limit of multiplex PCR, samples of DNA extracted from 7 types of herpes virus (HSV-1, HSV-2, VZV, EBV, CMV, HHV-6B, and HHV-7) were obtained by cloning PCR products using the pGEM-T Vector Systems kit (Promega, Madison, WI, USA). The cloned DNA was quantified by measuring optical density using a DU 800 spectrophotometer (Beckman Coulter, Fullerton, CA, USA), and the number of viral genome equivalent copies was calculated using an equation (16).
Extraction of DNA. Viral DNA was extracted from tissue culture-grown viruses $(200 \mu \mathrm{L})$, cell lines $\left(10^{6}\right.$ cells $)$, and clinical specimens $(200 \mu \mathrm{L})$. The QIAamp DNA mini kit (Qiagen GmbH, Hilden, Germany) was used for DNA extraction, and the DNA was eluted in $100 \mu \mathrm{L}$ of TE buffer $(10 \mathrm{mM}$ Tris-HCl, $\mathrm{pH}$ 8.0, and $1 \mathrm{mM}$ EDTA, $\mathrm{pH} 8.0$ ).

Primers for multiplex PCR. The sequences of the 6 primer sets used in the multiplex PCR assay are listed in Table 1. The primer was designed using the Primer3 program (development project hosted by SourceForge) based on the sequence of the DNA polymerase gene of human herpes viruses obtained from GenBank. The sequences were accessed using the following GenBank accession numbers: M10792 for HSV-1, M16321 for HSV-2, X04370 for VZV, NC_007605 for EBV, NC_001347 for CMV, NC_001664 for HHV-6A, AB021506 for HHV-6B, and NC_001716 for HHV-7. In order to amplify the DNA characteristics of each virus, our parameters included a longer primer chain length (26 or 27-mers) and similar melting temperatures (Nearest Neighbor Tm of $71.8 \pm 0.7^{\circ} \mathrm{C}$ ). Furthermore, in order to easily identify each product with agarose gel electrophoresis, we established expected amplifier product sizes of $292 \mathrm{bp}$ for $\mathrm{HSV}-1 / 2,161 \mathrm{bp}$ for VZV, 229 bp for EBV, 131 bp for CMV, 183 bp for HHV-6 A/B, and $347 \mathrm{bp}$ for HHV-7.

Multiplex PCR. We were able to detect 6 types of human herpes virus (HSV-1/2, VZV, EBV, CMV, HHV-6A/B, and HHV-7) by performing a multiplex PCR assay in a single tube. The reaction mixture $(50 \mu \mathrm{L})$ used in the multiplex PCR assay contained $5 \mu \mathrm{L}$ DNA extract, $1 \times$ GeneAmp PCR buffer $(10 \mathrm{mM}$ Tris- $\mathrm{HCl}, \mathrm{pH} 8.3,50 \mathrm{mM} \mathrm{KCl}$, and $0.001 \%$ [w/v] gelatin), $3.0 \mathrm{mM} \mathrm{MgCl}_{2}, 0.2 \mu \mathrm{M}$ of each primer (6 primer sets), $200 \mu \mathrm{M}$ deoxynucleotide triphosphates (dNTPs), and 2.0 U AmpliTaq Gold DNA polymerase (Applied Biosystems, Foster City, CA, USA). The assay was carried out using the GeneAmp PCR System 9700 (Applied Biosystems). After an initial denaturation and polymerase activation step at $95^{\circ} \mathrm{C}$ for $10 \mathrm{~min}$, the reactions were prolonged according to a touchdown protocol comprising 10 cycles of denaturation at $95^{\circ} \mathrm{C}$ for $30 \mathrm{~s}$, annealing at $70^{\circ} \mathrm{C}$ to $61^{\circ} \mathrm{C}$ for $30 \mathrm{~s}$ with a $1^{\circ} \mathrm{C}$ decrease in temperature per cycle, and extension at $72^{\circ} \mathrm{C}$ for $1 \mathrm{~min}$. Subsequently, the reaction mixture was subjected to 35 cycles of $95^{\circ} \mathrm{C}$ for $30 \mathrm{~s}, 60^{\circ} \mathrm{C}$ for $30 \mathrm{~s}$, and $72^{\circ} \mathrm{C}$ for $30 \mathrm{~s} \mathrm{(3).} \mathrm{After} \mathrm{the} \mathrm{last} \mathrm{cycle,}$ an additional extension step was performed at $72^{\circ} \mathrm{C}$ 
Table 1 Characters of primers used in the multiplex PCR assay

\begin{tabular}{|c|c|c|c|}
\hline $\begin{array}{c}\text { viruses of primers } \\
\text { (GenBank accession No.) }\end{array}$ & sequence $\left(5^{\prime}-3^{\prime}\right)$ & 5'-position & $\begin{array}{l}\text { predicted } \\
\text { product size } \\
\quad(\mathrm{bp})\end{array}$ \\
\hline $\begin{array}{l}\text { HSV-1/2 } \\
\text { (HSV-1: M10792, } \\
\text { HSV-2: M16321) }\end{array}$ & $\begin{array}{l}\text { F: GCCAAGAAAAAGTACATCGGCGTCATC } \\
\text { R: TGAGGACAAAGTCCTGGATGTCCCTCT }\end{array}$ & $\begin{array}{l}\text { HSV-1: } 3389 \\
\text { HSV-2: } 3058 \\
\text { HSV-1: } 3680 \\
\text { HSV-2: } 3349\end{array}$ & 292 \\
\hline $\begin{array}{l}\text { VZV } \\
(\mathrm{X} 04370)\end{array}$ & $\begin{array}{l}\text { F: TCCGACATGCAGTCAATTTCAACGTC } \\
\text { R: GGTCGGGTAGACGCTACCACTCGTTT }\end{array}$ & $\begin{array}{l}49651 \\
49811\end{array}$ & 161 \\
\hline $\begin{array}{l}\text { EBV } \\
\left(\mathrm{NC} \_007605\right)\end{array}$ & $\begin{array}{l}\text { F: CTTAGAATGGTGGCCGGGCTGTAAAAT } \\
\text { R: ATCCAGTACGTCTTTGTGGAGCCCAAG }\end{array}$ & $\begin{array}{l}153240 \\
153468\end{array}$ & 229 \\
\hline $\begin{array}{l}\text { CMV } \\
\left(\mathrm{NC} \_001347\right)\end{array}$ & $\begin{array}{l}\text { F: GCGCGTACCGTTGAAAGAAAAGCATAA } \\
\text { R: TGGGCACTCGGGTCTTCATCTCTTTAC }\end{array}$ & $\begin{array}{l}80362 \\
80492\end{array}$ & 131 \\
\hline $\begin{array}{l}\text { HHV-6A/B } \\
\text { (HHV-6A:NC_001664, } \\
\text { HHV-6B: AB021506) }\end{array}$ & $\begin{array}{l}\text { F: ATGCGCCATCATAATGCTCGGATACA } \\
\text { R: CCCTGCATTCTTACGGAAGCAAAACG }\end{array}$ & $\begin{array}{l}\text { HHV-6A: } 57837 \\
\text { HHV-6B: } 58791 \\
\text { HHV-6A: } 58019 \\
\text { HHV-6B: } 58973\end{array}$ & 183 \\
\hline $\begin{array}{l}\text { HHV-7 } \\
\text { (NC_001716) }\end{array}$ & $\begin{array}{l}\text { F: GCCCGTTTTCGGAAATATTGGAGAGAT } \\
\text { R: ACGCACGAGACGCACTTTTCTTAAACA }\end{array}$ & $\begin{array}{l}55671 \\
56017\end{array}$ & 347 \\
\hline
\end{tabular}

Primer design was based on the DNA polymerase genes of human herpes viruses. Sequences and positions of the primers were accessible to GenBank accession numbers. The product sizes were predicted from the positions which should be amplified.

for $5 \mathrm{~min}$. The amplified products were electrophoresed in 3\% agarose gel, stained with ethidium bromide, and photographed under ultraviolet (UV) light.

Qualitative detection by TaqMan PCR. DNA extracted from clinical specimens was amplified and identified with the TaqMan PCR method using previously reported primers and probes specific for herpes viruses $(9,11-13,23,24)$. We examined 6 types of human herpes virus (HSV-1/2, VZV, EBV, CMV, HHV-6A/B, and HHV-7) by performing TaqMan PCR in an individual tube. Briefly, the TaqMan PCR assay was performed with a $25-\mu \mathrm{L}$ reaction mixture containing $5 \mu \mathrm{L}$ of DNA extract, $12.5 \mu \mathrm{L}$ of $2 \times$ QuantiTect Probe PCR kit master mix (Qiagen), $200 \mathrm{nM}$ of primers, and $100 \mathrm{nM}$ of probes. Amplification and real-time fluorescence detection were performed using the ABI Prism 7000 sequence detection system (Applied Biosystems) and the following protocol: an initial denaturation and polymerase activation step at $95^{\circ} \mathrm{C}$ for $15 \mathrm{~min}$ followed by 50 cycles of denaturation at $95^{\circ} \mathrm{C}$ for $15 \mathrm{~s}$ and extension at $62^{\circ} \mathrm{C}$ for $1 \mathrm{~min}$. Signals that were detected above the threshold were considered positive. Sig- nals that were below the threshold were considered negative.

\section{RESULTS}

Characterization of multiplex PCR and its products An electropherogram of the multiplex PCR products showed that we obtained amplified fragments of the expected size when using the primer sets specific to the 6 types of human herpes virus (Table 1, Fig. 1). Furthermore, the base sequence was determined by a direct sequence method using an amplified product of each virus (25); thus, we confirmed amplification of the target virus DNA (data not shown). On the other hand, when DNA of other DNA viruses was used in PCR, no amplified product was detected (Fig. 2). When HSV-1 DNA was used in the multiplex PCR assay reaction mixture, we were able to obtain an amplified product of the expected size; however, when HHV-8 DNA was used, we were unable to obtain any product because primers specific to HHV-8 DNA were absent. In order to determine the limit of detection, multiplex PCR was performed using pre-diluted cloned DNA samples of the $6 \mathrm{hu}$ man herpes viruses. The sensitivity of this multiplex 


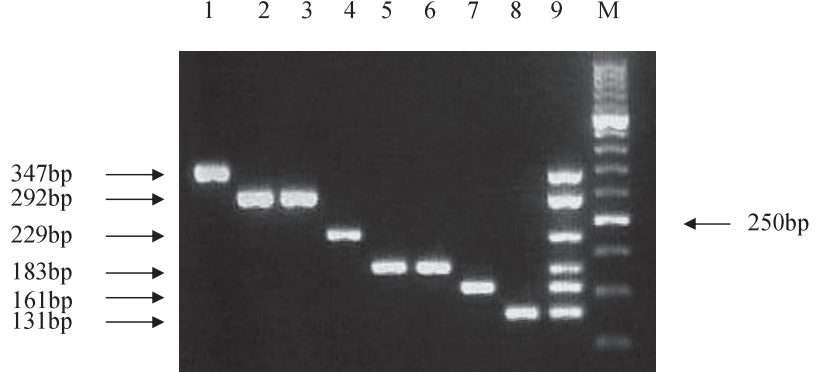

Fig. 1 Electropherogram of multiplex PCR products (Specificity 1). PCR was performed by standard methods using the 6 primer sets and viral DNA from one type of human herpes virus. Electrophoresis of PCR products was conducted in $3 \%$ agarose gel with a molecular size marker. Lane 1, HHV-7; lane 2, HSV-1; lane 3, HSV-2; lane 4, EBV; lane 5, HHV-6A; lane 6, HHV-6B; lane 7, VZV; lane 8, CMV; lane 9, HHV-7, HSV-1, EBV, HHV-6B, VZV and CMV; lane $\mathrm{M}$, size marker (50 bp ladder).

$\begin{array}{llllllllll}1 & 2 & 3 & 4 & 5 & 6 & 7 & 8 & 9 & \mathrm{M}\end{array}$

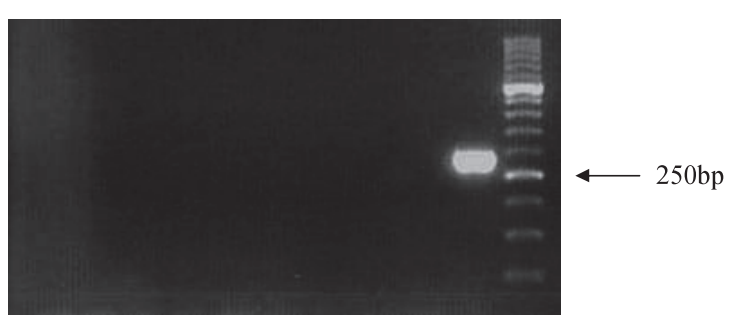

Fig. 2 Electropherogram of multiplex PCR products (Specificity 2). PCR was performed by standard methods using the primer sets for 6 types of human herpes virus and various viral DNA, including human herpes virus types 1 and 8. Electrophoresis of PCR products was conducted in $3 \%$ agarose gel with a molecular size marker. Lane 1, AdV-2; lane 2, HPV-16; lane 3, HHV-8; lane 4, HTLV-I; lane 5, parvovirus B19; lane 6, SV40; lane 7, HBV; lane 8, human genomic DNA; lane 9, HSV-1; lane $M$, size marker (50 bp ladder).

PCR was approximately 20 DNA copies of each virus per reaction (Fig. 3).

We conducted an experiment to investigate whether the amplification efficiency of multiplex PCR is affected when 2 types of virus are present in the same sample. When the size of the amplified fragment was short and amplification efficiency was high, we detected tenfold dilution series $\left(10^{2}\right.$ to $10^{5}$ copies) of cloned DNA from HSV-1, EBV, VZV, HHV-6, and HHV-7 in the presence of a large quantity of CMV genomic DNA ( $10^{4}$ copies), and we detected tenfold dilution series $\left(10^{2}\right.$ to $10^{5}$ copies) of cloned CMV DNA in the presence of a large quantity of the VZV genome ( $10^{4}$ copies). The sensitivity of the assay was unaffected by the presence of mul- tiple types of viral DNA; the results were comparable to those obtained when DNA from a single virus was present (Fig. 4).

\section{Comparison of multiplex PCR assay with TaqMan} $P C R$

We compared the results of TaqMan PCR and multiplex PCR using clinical samples. The same 20 clinical samples used for multiplex PCR were assayed by the TaqMan PCR method for detecting human herpes viruses. The data obtained from the multiplex PCR and TaqMan PCR assays were compared. All the results, including those obtained using specimens containing multiple types of human herpes virus as well as single human herpes viruses, were found to correspond with each other (Table 2).

\section{DISCUSSION}

There have been considerable advances in the field of viral diagnosis, which have been brought about by the introduction of the rapidly advancing PCR methods that enable the diagnosis of specific viral infections. However, most of the present diagnostic methods for infectious diseases target a single pathogenic agent. Different pathogenic agents often induce similar clinical symptoms, especially in the early stages of infection $(4,8,10,14,17,26,27)$. Therefore, the appropriate selection of target agents is very important for the rapid and accurate diagnosis and effective treatment of viral infections. Furthermore, when multiple target agents are involved in detection, difficulties with respect to cost and time may arise. Hence, we developed a multiplex PCR technique to simultaneously detect and identify DNA from 6 types of herpes viruses (HSV-1/2, VZV, EBV, CMV, HHV-6A/B, and HHV-7). Our aim was to develop a multiplex PCR analysis that would be effective for use as a standard screening procedure in general laboratories. Therefore, we developed a multiplex PCR technique that involves a single tube for PCR and agarose gel electrophoresis analysis, avoiding the use of complicated processes and expensive equipment. In order to prevent the formation of an extra band signal due to a nonspecific reaction or the reduction in detection sensitivity due to a primer dimer, we did not increase the number of primer sets more than necessary. For these reasons, we chose not to include primers directed against HHV-8 due to its low rate of infection in humans (6), and designed a primer that detected both HSV-1 and HSV-2, because the same antiviral drugs are used to treat infections with both 


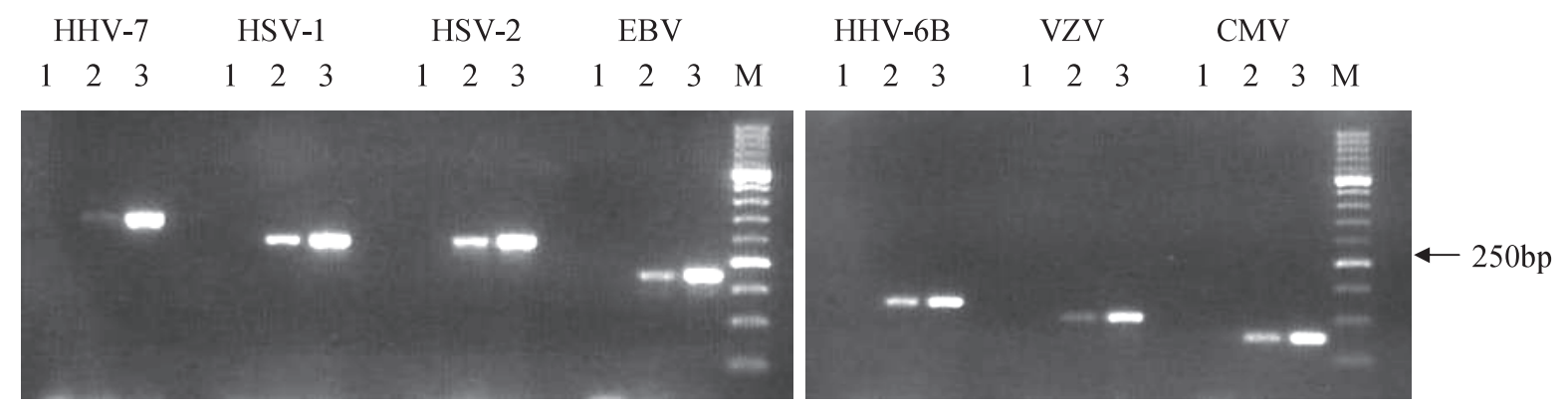

Fig. 3 Detection limit of multiplex PCR. PCR was performed by standard methods using the primer sets for 6 types of human herpes virus and cloned HSV-1, HSV-2, VZV, EBV, CMV, HHV-6B, and HHV-7 DNA. DNA was pre-diluted to 2, 20, and 200 copies per reaction. Electrophoresis of PCR products was conducted in $3 \%$ agarose gel with the molecular size marker. Lane 1, 2 copies; lane 2, 20 copies; lane 3, 200 copies; lane M, size marker (50 bp ladder).
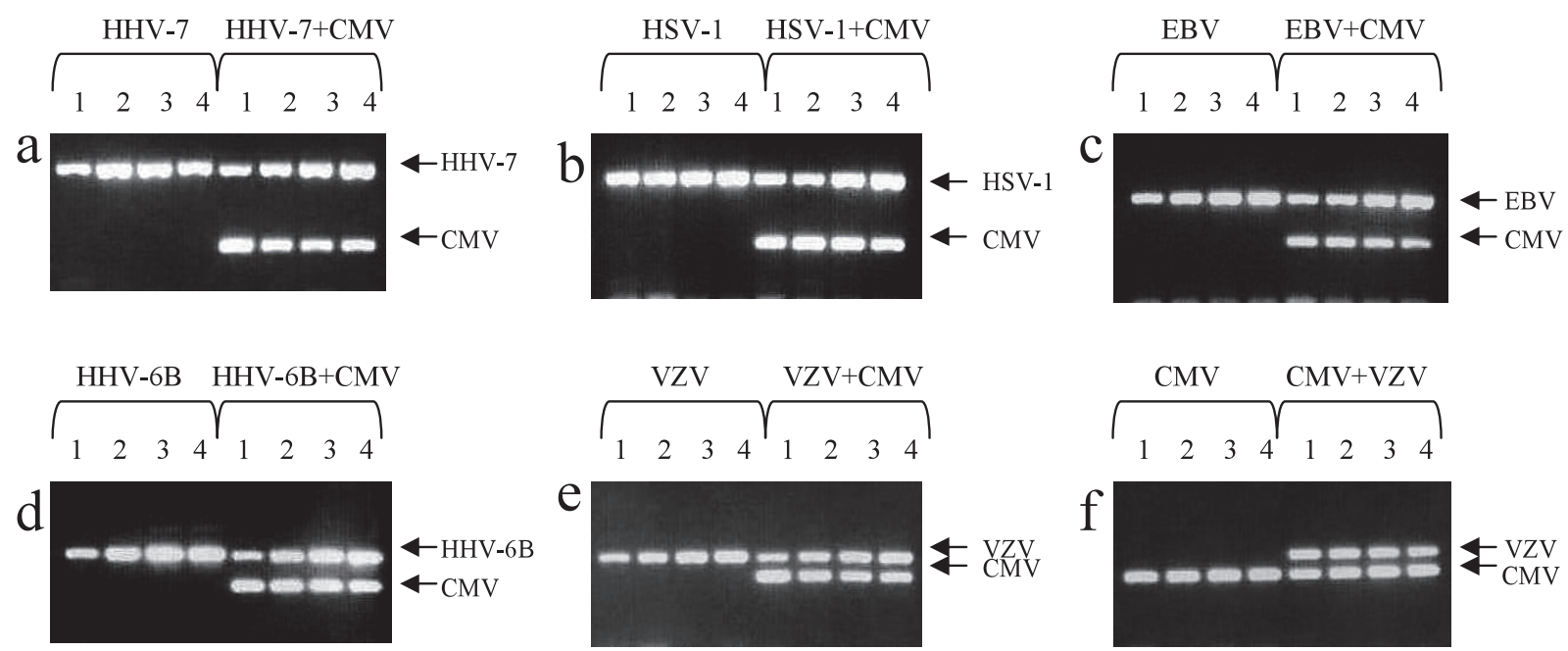

Fig. 4 Inhibition of PCR amplification by large amounts of viral genomic DNA during multiplex PCR. Tenfold dilution series of cloned DNA alone and cloned DNA mixed with $10^{4}$ copies of CMV genomic DNA were detected by multiplex PCR. Cloned DNA from the following viruses was tested: (a) HHV-7, (b) HSV-1, (c) EBV, (d) HHV-6B, and (e) VZV, (f) Tenfold dilution series of CMV cloned DNA and CMV cloned DNA mixed with $10^{4}$ copies of VZV genomic DNA. Lane $1,10^{2}$ copies of DNA; lane $2,10^{3}$ copies; lane $3,10^{4}$ copies; lane $4,10^{5}$ copies.

these viruses (19).

The multiplex PCR assay that we have developed for the detection of human herpes viruses facilitates easy virus detection and identification by agarose gel electrophoresis analysis (Table 1, Fig. 1). We found that the multiplex PCR assay was specific for 6 types of human herpes virus. Direct sequence analysis confirmed that the viruses that we detected and identified were the target viruses. In addition, nonspecific reactions with DNA from other viruses were not observed (Fig. 2). The detection limit for each virus was approximately 20 DNA copies per reaction, indicating high sensitivity (Fig. 3). Furthermore, the amplification efficiency of multiplex PCR was not affected when 2 types of virus were present in the same sample (Fig. 4). During evaluation using a clinical sample, it was found that the data obtained using this multiplex PCR technique corresponded to that obtained by using TaqMan PCR. We also obtained similar results when using samples containing multiple herpes viruses (Table 2). However, the effect on detection sensitivity is not known in instances in which many types of herpes virus are detected complexly or the quantities of multiple herpes viruses differ extraordinarily. The results obtained using samples (such as blood) from patients (such as immunosuppressed individuals) in whom many herpes viruses activate complexly may, in some cases, need to be carefully evaluated and assessed by conventional PCR.

Currently available simultaneous detection methods for human herpes viruses require complicated 
Table 2 Comparison of multiplex PCR and TaqMan PCR assay

\begin{tabular}{|c|c|c|c|c|c|c|c|c|}
\hline \multirow[t]{2}{*}{ sample } & \multirow[t]{2}{*}{ material } & \multirow[t]{2}{*}{ multiplex PCR } & \multicolumn{6}{|c|}{ TaqMan PCR } \\
\hline & & & HSV-1/2 & VZV & EBV & CMV & HHV-6A/B & HHV-7 \\
\hline 1 & blood & HHV-7 & - & - & - & - & - & + \\
\hline 2 & blood & HHV-7 & - & - & - & - & - & + \\
\hline 3 & $\mathrm{CSF}^{\mathrm{a})}$ & HSV-1/2 & + & - & - & - & - & - \\
\hline 4 & CSF & HSV-1/2 & + & - & - & - & - & - \\
\hline 5 & CSF & HSV-1/2 & + & - & - & - & - & - \\
\hline 6 & serum & EBV & - & - & + & - & - & - \\
\hline 7 & serum & EBV & - & - & + & - & - & - \\
\hline 8 & serum & EBV & - & - & + & - & - & - \\
\hline 9 & $\mathrm{CSF}$ & HHV-6A/B & - & - & - & - & + & - \\
\hline 10 & plasma & HHV-6A/B & - & - & - & - & + & - \\
\hline 11 & blood & HHV-6A/B & - & - & - & - & + & - \\
\hline 12 & $\mathrm{CSF}$ & VZV & - & + & - & - & - & - \\
\hline 13 & blood & VZV & - & + & - & - & - & - \\
\hline 14 & CSF & CMV & - & - & - & + & - & - \\
\hline 15 & blood & CMV & - & - & - & + & - & - \\
\hline 16 & plasma & CMV & - & - & - & + & - & - \\
\hline 17 & blood & CMV, HHV-6A/B & - & - & - & + & + & - \\
\hline 18 & blood & EBV, CMV & - & - & + & + & - & - \\
\hline 19 & blood & EBV, HHV-6A/B & - & - & + & - & + & - \\
\hline 20 & blood & EBV, CMV, HHV-6A/B & - & - & + & + & + & - \\
\hline
\end{tabular}

Using clinical specimens which were suspected of viral infection, the assay results were compared.

a): Cerebrospinal fluid

and specialized analysis processes such as southern blot hybridization and microarray methods $(28,29)$. Moreover, if 6 types of human herpes virus are to be detected, PCR with multiple tubes and requiring expensive equipment must be performed (22). Expensive equipment can be introduced into only a limited number of laboratories, and analysis processes involving complicated and specialized PCR methods must be performed by highly trained technicians to avoid contamination. The multiplex PCR technique that we developed enables the detection and identification of the 6 most frequently detected types of human herpes virus by utilizing gel electrophoresis, which is widely used for many types of PCR. Further, our method uses only one tube for the PCR reaction without expensive equipment or complicated processes. Multiplex PCR is superior both in sensitivity and specificity, and is therefore extremely useful as a quick and economically efficient screening test for the diagnosis of infectious diseases associated with human herpes viruses.

On the other hand, because multiplex PCR is a qualitative method of measurement, a human herpes virus, regardless of the stage of infection (i.e., even at a latent stage), may be detected in some samples obtained from healthy individuals; therefore, select- ing the appropriate sample source is essential. Further, we may simultaneously detect several viruses or even viruses that are not expected based on the symptoms observed. In these cases, the combined use of antibody tests and quantitative PCR may be subsequently employed to obtain a more precise diagnosis $(12,23)$.

\section{REFERENCE}

1. Burns WH and Sandford GR (1990) Susceptibility of human herpesvirus 6 to antivirals in vitro. $J$ Infect Dis 162, 634 637.

2. De Clercq E (1997) In search of a selective antiviral chemotherapy. Clin Microbiol Rev 10, 674-693.

3. Don RH, Cox PT, Wainwright BJ, Baker K and Mattick JS (1991) 'Touchdown' PCR to circumvent spurious priming during gene amplification. Nucleic Acids Res 19, 4008.

4. Echevarría JM, Casas I, Tenorio A, de Ory F and MartínezMartín P (1994) Detection of varicella-zoster virus-specific DNA sequences in cerebrospinal fluid from patients with acute aseptic meningitis and no cutaneous lesions. $J$ Med Virol 43, 331-335.

5. Evans AS (1978) Infectious mononucleosis and related syndromes. Am J Med Sci 276, 325-339.

6. Fujii T, Taguchi H, Katano H, Mori S, Nakamura T, Nojiri N, Nakajima K, Tadokoro K, Juji T and Iwamoto A (1999) Seroprevalence of human herpesvirus 8 in human immunodeficiency virus 1-positive and human immunodeficiency virus 1-negative populations in Japan. J Med Virol 57, 159-162. 
7. Gewurz BE, Marty FM, Baden LR and Katz JT (2008) Human herpesvirus 6 encephalitis. Curr Infect Dis Rep 10, 292 299.

8. Gurevich I (1992) Varicella zoster and herpes simplex virus infections. Heart Lung 21, 85-91.

9. Hara S, Kimura H, Hoshino Y, Tanaka N, Nishikawa K, Ihira M, Yoshikawa T and Morishima T (2002) Detection of herpesvirus DNA in the serum of immunocompetent children. Microbiol Immunol 46, 177-180.

10. Hoshino Y, Kimura H, Tanaka N, Tsuge I, Kudo K, Horibe K, Kato K, Matsuyama T, Kikuta A, Kojima S and Morishima T (2001) Prospective monitoring of the Epstein-Barr virus DNA by a real-time quantitative polymerase chain reaction after allogenic stem cell transplantation. Br J Haematol 115, $105-111$.

11. Ito Y, Kimura H, Yabuta Y, Ando Y, Murakami T, Shiomi M and Morishima T (2000) Exacerbation of herpes simplex encephalitis after successful treatment with acyclovir. Clin Infect Dis 30,185-187.

12. Kimura H, Morita M, Yabuta Y, Kuzushima K, Kato K, Kojima S, Matsuyama T and Morishima T (1999) Quantitative analysis of Epstein-Barr virus load by using a real-time PCR assay. J Clin Microbiol 37, 132-136.

13. Kimura H, Wang Y, Pesnicak L, Cohen JI, Hooks JJ, Straus SE and Williams RK (1998) Recombinant varicella-zoster virus glycoproteins $\mathrm{E}$ and I: immunologic responses and clearance of virus in a guinea pig model of chronic uveitis. $J$ Infect Dis 178, 310-317.

14. Klapper PE and Cleator GM (1997) Herpes simplex virus. Intervirology 40, 62-71.

15. Kleinschmidt-DeMasters BK and Gilden DH (2001) The expanding spectrum of herpesvirus infections of the nervous system. Brain Pathol 11, 440-451.

16. Leung AY, Suen CK, Lie AK, Liang RH, Yuen KY and Kwong YL (2001) Quantification of polyoma BK viruria in hemorrhagic cystitis complicating bone marrow transplantation. Blood 98, 1971-1978.

17. Limaye AP, Huang ML, Leisenring W, Stensland L, Corey L and Boeckh M (2001) Cytomegalovirus (CMV) DNA load in plasma for the diagnosis of CMV disease before engraftment in hematopoietic stem-cell transplant recipients. J Infect Dis 183, 377-382.

18. Mills J, Jacobson MA, O'Donnell JJ, Cederberg D and Holland GN (1988) Treatment of cytomegalovirus retinitis in pa- tients with AIDS. Rev Infect Dis 10 Suppl 3, S522-531.

19. Simmons A (2002) Clinical manifestations and treatment considerations of herpes simplex virus infection. J Infect Dis 186 Suppl 1, S71-77.

20. Sjöholm M I, Dillner J and Carlson J (2008) Multiplex detection of human herpesviruses from archival specimens by using matrix-assisted laser desorption ionization-time of flight mass spectrometry. J Clin Microbiol 46, 540-545.

21. Snoeck R, Andrei G and De Clercq E (1994) Chemotherapy of varicella zoster virus infections. Int $J$ Antimicrob Agents 4, 211-226.

22. Sugita S, Shimizu N, Watanabe K, Mizukami M, Morio T, Sugamoto Y and Mochizuki M (2008) Use of multiplex PCR and real-time PCR to detect human herpes virus genome in ocular fluids of patients with uveitis. Br J Ophthalmol 92, 928-932.

23. Tanaka N, Kimura H, Iida K, Saito Y, Tsuge I, Yoshimi A, Matsuyama T and Morishima T (2000) Quantitative analysis of cytomegalovirus load using a real-time PCR assay. $J$ Med Virol 60, 455-462.

24. Tanaka N, Kimura H, Hoshino Y, Kato K, Yoshikawa T, Asano Y, Horibe K, Kojima S and Morishima T (2000) Monitoring four herpesviruses in unrelated cord blood transplantation. Bone Marrow Transplant 26, 1193-1197.

25. Tanaka T, Kuroda K, Kobayashi M and Sato K (2001) Detection and typing of TT virus DNA genotype by the PCRRFLP method. Mol Cell Probes 15, 195-200.

26. Taplitz RA and Jordan MC (2002) Pneumonia caused by herpesviruses in recipients of hematopoietic cell transplants. Semin Respir Infect 17, 121-129.

27. Visser AM, van Doornum GJ, Cornelissen JJ and van den Bent MJ (2005) Severe amnesia due to HHV-6 encephalitis after allogenic stem cell transplantation. Eur Neurol 54, 233 234.

28. Yamamoto $T$ and Nakamura $Y$ (2000) A single tube PCR assay for simultaneous amplification of HSV-1/-2, VZV, CMV, HHV-6A/-6B, and EBV DNAs in cerebrospinal fluid from patients with virus-related neurological diseases. $J$ Neurovirol 6, 410-417.

29. Zheng ZB, Wu YD, Yu XL and Shang SQ (2008) DNA microarray technology for simultaneous detection and species identification of seven human herpes viruses. J Med Virol 80, 1042-1050. 
